\title{
MEMBANGUN TRADISI AKADEMIK PENDIDIKAN PESANTREN DALAM PEMBENTUKAN KARAKTER
}

\author{
Munib \\ STAI Nazhatut Thullab Sampang \\ Email: munib.cahayailmu@gmail.com
}

\begin{abstract}
Abstrak:
Menetapkan tradisi akademis dalam pendidikan di dunia sekunder lebih rendah adalah sesuatu yang penting di lembaga formal dan informal baik di sekolah, universitas maupun di Pondok Pesantren. Keberhasilan MAN 3 Malang dan MAN Malang II Batu sebagai institusi unggulan dibantu oleh hadirnya sekolah-sekolah pendidikan (Ma'had) di sekolah dengan tradisi pendidikan pesantren dan budaya pesantren (Ma'hady culture) sehingga Para siswa di samping dilengkapi dengan sains mereka juga mendapat bimbingan di bidang teologi. Penelitian ini bertujuan untuk mengungkap tradisi akademis di pesantren ma'had al-Qalam MAN 3 Malang dan pesantren (ma'had) siswa al-Ulya MAN Malang II Batu dalam pembentukan karakter, dengan sub-fokus. meliputi: (1) tradisi akademik pendidikan pesantren, (2) nilai-nilai luhur tradisi Pondok Pesantren dalam membentuk karakter siswa yang menjadi tradisi atau budaya ma'had al-Qalam MAN 3 Malang dan ma'had al Ulya MAN Malang II Batu.
\end{abstract}

Kata Kunci: Tradisi Akademik, Pendidikan, Karakter

\begin{abstract}
:
Establishing an academic tradition in education in the world of lower secondary is something that is important in the formal and informal institutions be it in schools, universities and in the Boarding School. The success of MAN 3 Malang and MAN Malang II Batu as a superior institution is helped by the presence in schools of education (Ma'had) in the school with a tradition of academic and cultural boarding school education(Ma'hady culture) so that the students in addition equipped with the science they also received guidance in the field of theology. This study aims to reveal the academic tradition in the boarding school( $\mathrm{ma}^{\prime}$ 'had $)$ al-Qalam MAN 3 Malang and boarding school ( $\mathrm{ma}^{\prime}$ 'had) al-Ulya MAN Malang II Batu students in the formation of character, with a sub-focus include: (1) academic tradition of boarding school education, (2) the noble values of the Boarding School tradition in forming the
\end{abstract}


character of students who become a tradition or culture in ma'had al-Qalam MAN 3 Malang and ma'had al-Ulya MAN Malang II Batu.

Keywords: Academic Tradition, Education, Character

\section{Pendahuluan}

Perkembangan pendidikan Islam di Indonesia dalam berbagai bentuk telah berlangsung sejak sekian lama dari zaman prakemerdekaan sampai sekarang, sehingga kebijakan penataan dan pemberdayaan pendidikan Islam di Negara kita selalu memperhatikan dua aspek strategis, yakni : pertama, aspek kontinuitas tujuan, substansi dan jatidiri pendidikan Islam. Kedua, aspek inovasi dan transformasi yang memungkinkan pendidikan Islam memiliki keunggulan koparatif dan kompetitif di dalam system pendidikan nasional.

Dalam Undang-Undang terbaru No 20 Tahun 2003 tentang Sistem Pendidikan Nasional dan Peraturan Pemerintah Nomor 55 Tahun 2007 tentang Pendidikan Agama dan Keagamaan merupakan matarantai kebijakan yang pada akhirnya menempatkan lembaga pendidikan agama dan keagamaan di bawah Departemen Agama setara dengan pendidikan alainnya. Pengakuan kesetaraan pendidikan Islam seperti pesantren dan madrasah diwujudkan dengan menyertakan regulasi, program serta anggaran yang disediakan Pemerintah melalui APBN. ${ }^{1}$ Dengan demikian, diharapkan peningkatan kualitas pendidikan Islam termasuk pesantren secara menyeluruh dapat tercapai.

Pesantren sebagai bagian dari pendidikan Islam harus senantiasa memerankan fungsi dan misi profetisnya dalam peningkatan kualitas SDU-nya, baik dalam penguasaan sains dan tegnologi maupun dalam hal karakter, sikap dan moral, penghayatan dan pengamalan ajaran agama. ${ }^{2}$ Dengan kata lain, pesantren secara ideal harus berfungsi dan berperan membina dan menyiapkan santri yang berilmu, berteknologi, berketerampilan tinggi, dan sekaligus beriman dan beramal saleh. Pesantren harus mampu mengejar ketertinggalan-ketertinggalan dalam menyiapkan SDU yang berkualitas. Juga tidak kalah pentingnya dari

1 Muhammad M. Basyumi, Kata Sambutan Menteri Agama RI, dalam Asrori S. Karni, Etos Studi Kaum Santri, Wajah Baru Pendidikan Islam,(Bandung: PT Mizan Pustaka, 2009), ix

2 Babun Suharto, Dari Pesantren Untuk Umat: Reinventing Eksistensi Pesantren di Era Globalisasi, (Surabaya: Imtiyaz, 2011), 71 
itu semua adalah pesantren harus mengorientasikan diri dalam menjawabkebutukan dan tantangan yang terus muncul di tengah masyarakat sebagai konsekuensi dari laju perubahan yang terus menerus. Untuk itu, tidak ada alternatif lain, kecuali penyiapan SDU yang berkualitas tinggi, menguasai ilmu pengetahuan dan teknologi, serta kehliaan dan keterampilan. Hanya dengan tersedianya SDU yang berkualitas tinggi itu, Indonesia bisa survive di tengah pertarungan ekonomi dan politik yang terus kian kompetitif.

Pendidikan pesantren kalau dilihat dalam konteks sejarah dan perjalanan Islam di Indonesia, maka dapat dikatakan bahwa pesantren, termasuk madrasah beserta lembaga-lembaga pendidikan Islam lainnya sudah terlalu lama berada dalam pinggiran, dengan segala konsekwensinya termasuk di dalamnya terkait kualitasnya pendanaan dari pemerintah, dan seterusnya. Karena itu jika kita ingin konsisten dengan cita-cita dan harapan keumatan, bahwa anak-anak santri juga harus unggul dalam berbaagai bidang keilmuan termasuk yang prospektif dan menjanjikan dari sudut lapangan kerja maka perkembangan terkini pendidikan Islam harus banyak disyukuri. Adanya anggapan bahwa madrasah dan juga pesantren serta lembaga-lembaga pendidikan Islam lainnya sebagai persemaiaman radikalisme jelas keliru, dengan adanya pengarusutamaan (mainstreaming) madrasah dan lembaga-lembaga pendidikan Islam lainnya justru menganggkat harkat dan mertabat madrasah, sehingga semakin banyak orang tua yang menyekolahkan anak-anak mereka di madrasah. Disinilah kemudian muncul rasa kebanggaan keumatan untuk menggatikan rasa keterpinggiran yang pernah menyelimuti kehidupan umat di negeri tercinta ini. ${ }^{3}$

Salah satu model dalam perkembangan pendidikan Islam di Indonesia adalah model pesantren (Ma'had). Yang dimaksud dengan model pesantren disini adalah system belajar-mengajar yang mana santri(siswa) sudah ditempatkan di asrama, memiliki masjid dan mata pelajaran berupa kitab-kitab yang beragam di bawah bimbingan satu kyai dan dibantu oleh beberapa Ustazd. ${ }^{4}$ Penanaman akhlak adalah taradisi yang sangat dipentingkan didunia pesantren. Akhlah kepada sesama teman, kepada masyarakat sekitar, terlebih-lebih kepada kiai. Terhadap sesama

3 Azyumardi Azra, Prolog, Wajah Baru Pendidikan Islam: Pengarusutamaan, dalam Asrori S. Karni, Etos Studi Kaum Santri, Xix

4 Abdur Rahman Assegaf, Pendidikan Islam di Indonesia, (Yogyakarta: SUKA Press, 2007), 88 
teman dijga betul sehingga tidak timbul sengketa dan ukhuwah islamiah selalu dijaga. Tehadap masyarakat sekitar perlu dijaga, agar cirta pesantren tidak luntur dimata masyarakat. Akhlak terhadap guru atau kiai sangat dutamakan, bebab dari kiailah santri memperoleh ilmu pengetahuan. Durhaka kepada kiai bisa berakibat tidak berkahnya ilmu. Jadi dalam kehidupan pesantren, penghormatan kepada kiai penempati posisi penting. nasihatnasihatnya, patuah-patuahnya selalu diperhatikan.

Diantara tradisi yang dibangun dipesantren adalah menjaga hubungan antara santri dan kiai tidak hanya berlaku selama santri berada dalam lingkungan perantren, hubungan tersebut berlajut kendatipun santri tidak lagi berada secara formal di pesantren. Pada waktu-waktu tertentu alumni santri mendatangi kiai(sowan). Selain dari itu hubungan santri dengan kiai tidak hanya menyangkut dalam hal yang berkenaan dengan proses belajar mengajar, tetapi lebih dari itu. Dalam hal-hal yang amat pribadi pun sifatnya, selalu ditanyakan santri kepada kiai, dan kiai pun selalu pula memberikan pandangan-pandangan tentang berbagai kesulitan yang dialami santri. Sesuai dengan tujuan pesantren, ${ }^{5}$ dapat dilihat bahwa penekanan yang amat dipentingkan dalam menuntut ilmu adalah keikhlasan.

Pendidikan Islam termasuk pesantren jika kita cermati memiliki watak khas dan karakter yang cukkup unik. Semenjak awalnya, baik dari system langgar dan halaqah maupun pesantren tampak lebih merupakan inisiatif apriori, yang erat kaitannya dengan penyebaran ajaran islam itu sendiri dalam pengertiannya yang sangat sederhana di satu sisi, dan di sisi yang lain menunjukkan lemahnya infra-struktur dan supra struktur tanpa landasan prakdimatis yang matang. Hal ini misalnya dapat kita amati dari tujuan para kiai mendirikan pondok dan menyebarluaskan ilmu agamanya yang semata-mata ibadah dan

5 Menurut hasil penelitian Mastuhu, bahwa tujuan pendidikan di pesantren adalah menciptakan dan mengembanhkan kepribadian muslim yaitu kepribadian yang beriman dan bertakwa kepada tuhan, berakhlak mulia, bermanfaat bagi masyarakat atau berkhidmat kepada masyarakat dengan jalan menjadi kaula atau mengabdi kepada masyarakat seperti Rasul, yaitu menjadi pelayan masyarakat sebagaimana kepribadian Nabi Muhammad (mengikuti sunnah Nabi), mampu berdiri sendiri, bebas dan teguh dalam pendirian, menyebarkan atau menegakkan Islam dan kejayaan umat Islam ditengah-tengah masyarakat ('izzul Islam wal muslimin), dan mencintai ilmu dalam rangka mengembangkan kepribadian bangsa Indonesia(mastuhu, 1990, 148, dalam Haidar Putra Daulay, Sejarah Pertumbuhan dan Pembaruan Pendidikan Islam di Indonesia (Jakarta: Kencana, 2007), 70 
mencari ridha Allah dari sisi ini, kita memahami kelambanan dan kurang progresivitasnya system system pendidikan Islam seperti pesantren. Namun demikian dalam proses perkembangannya dari model pesantren ke madrasah dan dari madrasah ke sekolah tampak dialektis. Artinya proses perkembangan itu banyak dipengaruhi dan didukung oleh beragam fenomena sosial-budaya yang relative kompleks. Kompleksitas fenomena sosial-budaya yang melingkupinya menimbulkan perbedaan ciri dan karakterristik perkembangan dan perubanhan terhadap pendidikan Islam tersebut. Pesantren misalnya memiliki corak perkembangan yang lambat. Karena bersifat konservatif bahkan dalam beberapa hal defensive dan konprontatif, ${ }^{6}$ meskipun sebagian daripadanya melakukan hal yang berbeda-beda. ${ }^{7}$

Model-model lembanga pendidikan Islam akhir-akhir ini banyak bermunculan Pesantren misalnya, pesantren tidak lagi hanya di wilayah-wilayah terpencil atau di daerah pinggiran akan tetapi Pesantren sudah mulai ramai di berbagai tempat bahkan ditengah-tengah kota. pesantren (Ma'had) al-Qalam yang MAN 3 Malang yang berada di jalan Bandung Malang di bawah naungan madrasah unggulan. dan pesantren (Ma'had) al-Ulya MAN Malang II Kota Batu. Keduanya menjadi salah satu model yang memiliki tradisi akademik yang dapat menjawab persoalan dan tantangan era globalisasi yang kian mengkikis moral anak bangsa. Selain itu model pesantren sudah mulai ada di level sekolah tinggi seperti UIN Maulana Malik Ibrahim Malang yang sedikit banyak tentunya akan memberikan nuansa beda terhadap pendidikan model pesantren ini. Pendidikan Karakter akhir-akhir ini menjadi pembicaraan yang hangat dikalangan masyarakat umum, terlebihlebih dalam masyarakat pendidikan. Wacana pendidikan karakter muncul secara terus bukan semata-mata di sebabkan oleh kebijakan Menteri Pendidikan Nasional melainkan lebih jauh disebabkan oleh adanya keprihatinan masyarakat terhadap dekadensi moral yang tidak kunjung selesai, serta masih banyaknya kejadian konflik antar kelompok, suku bangsa, golongan, dan status sosial yang mengancam persataun dan kesatuan.

${ }^{6}$ Corak ini merupakan representasi dari pesantren salaf (tradisional), yang tidak banyak melakukan asimilasi dan proses adopsi terhadap dinamika socialbudaya yang terjadi. Inilah corak yang defensive. Dan corak konfrontatif bisa kita lihat isolasi pesantren di wilwyah-wilayah pedalaman, sebagai suatu perlawanan terhadap pemerintah kolonil.

${ }^{7}$ Abdul Rahman Assegaf, Pendidikan Islam, 95 
Adanya ma'had di lingkungan sekolah atau madrasah bisa jadi sebagai langkah yang efektif dalam pembetukan karakter siswa dengan menanamkan nilai-nilai keagamaan sebagai tambahan materi pembelajaran ektra madrasah seperti di MAN 3 Malang dan MAN Malang II Kota Batu. Ma'had Al-Qalam MAN 3 Malang adalah ma'had yang di sediakan MAN 3 Malang bagi siswa-siswi yang ingin mendapatkan pengajaran lebih tentang ilmu-ilmu agama, dan bagi siswa/siswi yang tempat tinggalnya jauh dari sekolah MAN 3 Malang. Ma'had adalah sarana tempat tinggal dan pembelajaran ilmu agama bagi santri/siswa-siswi yang tinggal di ma'had . Disini Santri diajarkan banyak hal tentang keagamaan, seperti kajian kitab, solat berjama'ah dan lain-lainnya. Di Ma'had juga santri dilatih untuk menjadi siswa-siswi yang pandai dalam keorganisasian seperti OSIMA (Organisasi Intra Ma'had) organisasi sepertihalnya osis di sekolah akan tetapi anggota osima di latih mengelola tentang apa yang ada di ma'had.

Di Ma'had juga santri di latih dalam kepanitiaan seperti mengurus panitia pondok ramadhan, penerimaan santri baru, pekan bahasa dan lain-lain. Ma'had juga memfasilitasi para santri dalam kegiatan-kegiatan yang ada di sekolah seperti diadakannnya jam Tutorial, yakni para santri belajar di dalam kelas-kelas pada malam hari setelah solat Isya' dengan guru-guru yang sengaja di datangkan oleh ma'had.

Ponpes Al-Ulya di Jalan Patimura, Kelurahan Temas ini yang peduli menampung dan memberikan pendidikan agama hingga pengetahuan umum pada anak-anak yang tidak mendapat perhatian dalam pendidikan seperti anak jalanan, ketika daerah lain masih kesulitan menanggani kelompok anak-anak itu. Walaupun sudah nyantri, sebagian dari mereka pun masih bisa keluar untuk ngamen. Komplek Ma'had Al-Ulya, berada di belakang atau selatan gedung Madrasah Aliyah Negeri (MAN) Malang II Kota Batu. Bangunannya tergolong baru, selain dilengkapi ruang kegiatan belajar mengajar, musala, ketrampilan, juga disiapkan kamar-kamar tidur dalam bentuk ruangan. Ponpes tersebut, memang milik MAN Malang II Kota Batu madrasah yang dinaungi Kementrian Agama ini. Dan di tempat ini, anak jalanan memang mendapatkan fasilitas tempat tinggal, mengaji, hingga kebutuhan belajar.

Ma'had al-Ulya MAN Malang II Kota Batu pada dasarnya adalah termasuk lembaga pendidikan yang memilki kesamaan tradisi dengan pesantren pada umumnya, dari sisi pembelajaran mengenai keagamaan dan penanaman nilai-nilai akhlakul karimah. 
Secara struktural ma'had al-Ulya berada dalam naungan MAN Malang II Kota Batu sebagai fasilitas para siswa-siswi yang ingin tinggal di ma'had guna memperdalam tentang ilmu agama, namun selain itu ma'had juga menampung anak jalanan yang kurang mendapt perhatian dalam bidang pendidikann sehingga mereka dapat fasilitas baik tempat tinggal dan fasilitas belajar.

Dari beberapa penjelasan di atas bagaimana pesantren merupakan salah satu system pendidikan islam yang efektif dalam mewujudkan cita-cita pendidikan nasional dan perlunya penanaman nilai-nailai ahklakul karimah pada anak didik maka peneliti tertarik untuk mengangkat judul " Membangun Tradisi Akademik Pesantren Dalam Pembentukan Karakter Santri di Pesantren Al-Qalam MAN 3 Malang dan Ma'had Al-Ulya MAN Malang II Kota Batu"

\section{Pendidikan Pesantren}

Dalam sejarahnya, pesantren dikenal sebagai lembaga pendidikan Islam yang tertua di Indonesia. Keberadan pesantren dalam berbagai aspek kehidupan dan perjuangannya ternyata memiliki nilai strategis dalam membina insane yang berkualitas iman, ilmu, dan amal. ${ }^{8}$ Hal ini dapat dibuktikan dalam sejarah bangsa Indonesia di mana darinya bermunculan para ilmuan, politikus dan cendikiawan yang memasuki berbagai kancah percaturan di segala bidang sesuai dengan disiplin ilmu yang mereka miliki, baik dalam tarap local, regional maupun nasional bahkan sampai internasional. ${ }^{9}$

Pada dasarnya, lahirnya pesantren tidak terlepas dari proses islamisasi di Indonesia. Para wali, kiai, syekh, tengku, yang

8 Dalam Islam, ilmu itu merupakan persoalan pokok dalam ajarannya. Al-Qur'an dan hadist Nabi sering menyebutkan pentingnya ilmu, sebagaimana telah ditegaskan dalam surat $\mathrm{Al}$ Mujadilah ayat 11:

“... Allah akan meninggikan orang-orang yang beriman di antaramu dan orangorang yang diberi ilmu pengetahuan beberapa derajat....". Dan hadits Nabi yang diriwayatkan oleh Imam Muslim dan Abu Hurairah: "Dan barang siapa yang menempuh jalan menuju ilmu, maka Allah akan mempermudah baginya jalan ke surga". Ilmu dalam Islam merupakan sarana (instrument atau metode) untuk memahami dan memberi kejelasan dari petunjuk agama yang global dalam al-Qur;an sebagai kalam Allah dan hadits Nabi, serta memperoleh kejelasan tentang alam semesta ang terbentang sebagai ciptaan Allah, untuk dikomonikasiakan kepada manusoia dan difungsikan dalam kehidupan dalam rangka menyempurnakan iman, Islam dan ihsan.

9 M. Ridlwan Nasir, Mencari Tipologi Format Pendidikan Ideal: Pondok Pesantren di Tengah Arus Perubahan, (Jakarta: Pustaka Pelajar, 2005), 84. 
mendakwakan ajaran islam biasanya memiliki lembaga pendidikan ersebut. Di jawa terkenal dengan nama pesantren, di Sumatera Barat disebut surau, sedang di Aceh meunasah, rangkang dan dayah. Walaupun memiliki nama yang berbeda-beda, namun hakikatnya tetap sama, yaitu lembaga tempat mengkaji dan mendalami ajaran-ajaran keislaman. 10 Dengan demikian, inti pokok dari suatu pesantren adalah pusat pengkajian ilmu-ilmu keagamaan islam, seperti fikih, tauhid, tafsir, hadis, tasawuf, bahasa Arab, dan lain sebagainya.

Pada awal pertumbuhan pesantren sampai datangnya masa perubahan sekitar awal abad kedua puluh, pesantren belum mengenal apa yang dissebut dengan ilmu-ilmu umum dan begitu juga system penyampaian belum bersifat klasikal, serta hafalan metodenya memakai metode wetonan dan sorogan. Masuknya peradaban barat ke Indonesia melaui kaum penjajah belanda memengaruhi corak dan pandangan bangsa Indonesia, termasuk dalam dunia pendidikan sehingga dengan demikian timbul upayaupaya pembaruan dalam dunia pendidikan Islam.

Sedangakan fungsi pesantren menurut Ma'shum, mencakup tiga fungsi yaitu fungsi religious(diniyah) fungsi social (ijtimaiyah) fungsi edukasi (tarbawiayah). Ketiga fngsi ini masih berlangsung hingga sekarang. A. wahid Zaeni menegaskan bahwa disamping lembaga pendidikan, pesantren juga sebagai lembaga pembinaan moral dan cultural, baik dikalangan santri maupun santri dengan masyarakat. Kedudukan ini memberi isyarat bahwa penyelenggaraan keadilan social melaui pesantren lebih banyak menggunakan pendekatan cultural. ${ }^{11}$

Pendidikan merupakan upaya belajar dengan bantuan orang lain untuk mencapai tujuannya. Maksud tujuan pendidikan atau belajar untuk mencari ilmu ialah suatu kondisi tertentu yang dijadikan nacuan untuk menentukan keberhasilan belajar atu keberhasilan pendidikan. Menurut al-Jamaliy ${ }^{12}$ antara lain ialah (1) agar seseorang mengenal statusnya diantara makhluk dan tanggungjawab masing-masig individu didalam hidup mereka di dunia, (2) agar mengenal interaksinya dengan masyarakat dan tanggung jawab mereka ditengah-tengah sistem

${ }^{10}$ Haidar Putra Daulay, Sejarah Pertumbuhan dan Pembaruan Pendidikan Islam di Indonesia (Jakarta: Kencana, 2007), 72.

11 Mujamil Qomar, Pesantren: Dari Transformasi Metodologi Menuju Demokratisasi Institisi, (Jakarta: PT. Gelora Aksara Pratama), 23.

12 Al-Jamaliy ialah Muhammad Faadhil al-Jamaliy Penulis Kitab "Tabiyah al-Insan al-Jadid" Tunisia, 1967. 
kemasyarakatan,(3) supaya mereka kenal alam semesta dan membimbingnnya untuk mencapai hikmat Allah di dalam menciptakan alam semesta dan memungkinkan manusia untuk menggunakanya, (4) supaya manusia kenal akan tuhan pencipta alam semesta ini dan mendorongnya untuk beribadah. Sedangkan menurut al-Zarnuji tujuan belajar atu pendidikan islam sebagai berikut:

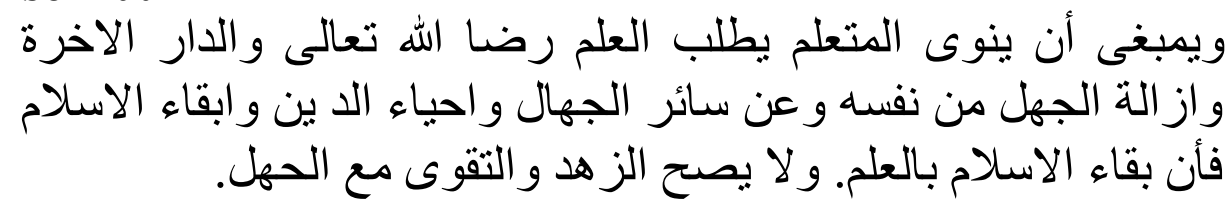

Maksudnya: seseorang yang menuntut ilmu ilmu harus bertujuan mengharap rihda Allah, mencari kebahagian di akhirat, menghilang-kan kebodohan baik dari dirinya sendiri maupun dari orang lain, menghidupkan agama, dan melestarikan Islam. Karena Islam itu dapat lestari, kalu pemeluknya berilmu. Zuhud dan taqwa tidak syah tanpa disertai ilmu. ${ }^{13}$

Jadi pada dasarnya tujuan dri belajar ialah bagaimana seseorang itu bisa mendapatkan ridha Allah baik di dunia maupun di akhirat. Selain itu tujuan dari belajar ialah untuk menghilangkan kebodohan dan meninggikan agama Allah, sebab unuk meninggikan agama Allah itu tidak mungkin dilakukan tanpa ilmu, maka dari itu seorang muslim di tuntut untuk mencari ilmu sejak ia masih dalam pangkuan ibunya sampai menjelang kematiannya.

Kelebihan dan Ciri-Ciri Umum Pendidikan Pesantren, Tradisi pesantren merupakan kerangka system pendidikan Islam tradisional di jawa dan Madura, yang dalam perjalanan sejarahnya telah menjadi objek penelitian para sarjana yang mempelajari islam di Indonesia yaitu sejak Brumund menulis sebuah buku tentang system pendidikan di jawa pada tahun 1871 yang kemudian diikuti oleh sebuah karya yang lain. Sarjana-sarjana seperti Van den Beng, hurgronye Geertz yang betul-betul menyadari tentang pengaruh kuat dari pesantren dalam membentuk dan memelihara kehidupan social, cultural, polotik dan keagamaan, mengetahui hanya sebagaian kecil saja dari cirri-ciri pesantren. ${ }^{14}$ Kebanyakan gambaran mereka tentang kehidupan pesantrern hanya menyentuh aspek keserhanaan bangunanbangunan dalam lingkungan pesantren, kesederhanaan hidup para

13 Maragustam " Pemikitan al-Zarnuji dalam Kitab Ta'lim al-Muta'allim Tentang Pemikiran Pendidikan Islam: Telaah dalam Perspektif Filsafat Pendidikan" dalam Abdur Rahman Assegaf ,dkk, Pendidikan Islam, 51

14 Zamahsari Dhofier, Tradisi, 38. 
santri, kepatuhan mutlak para sanrti kepada kiyainya dan dalam beberapa hal, pelajaran-pelajaran dasar mengenai kitab-kitab islam klasik.

Ada beberapa kelebihan yang dimiliki pesantren,dan kelebihan ini sekaligus menjadi cirri pesantren itu sendiri, yaitu: Pesantren mempunyai nilai-nilai kebangsaan atau nasionalisme, maupun patriotisme. Namun yang mengungkap sumbangsih besar pesantren ini ternyata kecil sekali. Hal ini mungkin karena terlalu banyak berpegang pada prinsip lillahi Ta'ala (semata-mata karena Allah) serta qana'ah (menerima apa adanya).

Tradisi pesantren tidak ada pembatasan peserta didik. Dalam artian para kiyai tidak pernah membatasi para santrinya dari suku, ras, bahkan agama sekalipun. Dari sinilah terjadi apa yang namanya pruralisme dalam arti etnik. Keterbukaan pesantren juga berlaku kepada mereka yang berlatar belakang bukan putra kiyai, bahkan juga kapada calon sanrti yang memilki kecukupan secara materi. Dengan demikian strata social tidsak menjadi hambatan.

Pada umumnya di pesantren ada tradisi fiqh. Seperti diketahui bahwa fiqh adalah hasil ijtihad. Dalam ijtihad tersebut terdapat ikhtilaf al-fuqha' (perbedaan ahli fiqh) atau ulama. Dan distu kita akan dihadapkan dengan berbagai perbedaan. Dan hal itu adalah fenomina yang biasa.

Pesantren mengenal tradisi tasawuf. Ketika berbicara masalah tasawuf akan terlihat inklusifitasnya. Bahkan sekat-sekat agama tidak diperhatikan sama sekali.

Dalam pesantren juga ada kebiasaan akomodasi. Hal yang ditradisikan di pesantren adalah perubahan yang dilakukan haruslah perlahan-lahan, tidak revolusioner. Kaidah almuhafadhah 'ala qadim al-shalih wa al-akhdu bi al-jadid al-aslah (menjaga atau memelihara hal-hal terdahulu yang baik dan mengambil hal-hal baru yang lebih baik) adalah hal penting yang hingga kini masih di pegang kuat di pesantren. ${ }^{15}$

Dari beberapa kelebihan-kelebihan yang suadah menjadi tradisi di pesantren pada lazimnya, maka pendidikan pesantren memilkiki nilai plus ketimbang pendidikan yang lain.

Tuntutan akan out put lembaga pendidikan islam yaitu pesantren yang bermutu semakin mendesak karena semakin keatatnya persaingan salam lapangan kerja yang serasi dengan kebutuhan stakeholders pesantreb. Oleh sebab itu lembaga-

15 Binti Maunah, Tradisi Intelektua Santri: Dalam Tantangan Dan Hambatan Pendidikan Pesantren di Masa Depan, (Yogyakarta: TERAS, 2009), 22. 
lembaga penyelengara pendidikan Islam berupaya untuk mengoptimalkan system dan program kerjanya segingga maksimalisasi produktivitas pendidikan dapat diwujudkan secara efektif dan efisien. Untuk itu fmutu pelayanan pendidikan perlu dikelola atau di-manej dengan baik sehingga pelayanan pendidikan dapat ditinglkatkan secara maksimal. Hal ini berarti bahwa penerapan system penjaminan mutu (qualy assurance) dalam manajemen mutu pendidikan pesantren dipandang penting dalam mengatasi pelaksanaan otonomi daerah atau desentralisasi dalam sector pendidikan, serta dalam pelaksanaan system manajemen pendidikan pesantren. ${ }^{16}$

Bagi pesantren, mutu pendidikan yang mengacu pada out put harus mengahasilkan dua arah yaitu: pertama; terciptanya ulama' yang dapat mengakomodir seluruh fenomina kehidupan sesuai dengan ajaran atau dasar al-Qur'an dan Hadist. Kedua; terbentuknya manusia yang mempunyai skill kompetitif di bidang ilmu pengetahuan dan teknologi (ITC) sesuai perkembangan zaman. ${ }^{17}$ Kemampuan pesantren dalam mengintegralkan mutu pendidikan ini merupakan bentuk keharusan yang secara akselerasi membutuhkan rekonsrtuksi atau bahkan dekonstruksi terhadap sistem yang ada. Walaupun di satu sisi khususnya dalam kontek ilmu pengetahuanseperti kedokteran, asrtonomi dan lain sebagainya, khazanah klasik yaitu dikenal dengan kitab kuning banyak memuat tentang hal itu.

\section{Tradisi Akademik Pendidikan Pesantren}

Pengertian Tradisi Akademik, Tradisi Akademik yang dimaksudkan adalah kebiaasan-kebiasan pesantren yang menjadikan cirri khas pesantren dalam kaitannya dengan masalah yang berkaitan system pembelajaran, kurikulum yang di pakai dan metode yang di gunakan. Pada umumnya pesantren tidak lepas dari kitab-kitab klasik seperti nahwu sharaf, aqidah dan fiqh, biasanya tindak lanjut dari kajian materi kitab mengacu kepada ilmu mantiq(logika) usul fiqh, Alfiah (grammaar tingkat tinggi), dan tasawwuf. Disamping itu diajarkan pula ulum al-Qur'an (ilmu-ilmu al-Qur'an)dan ulum al-Hadist(ilmu-ilmu hadist). ${ }^{18}$ Tradisi ; aadah

16 Umiarso \& Nur Zazin, Pesantren di Tengah Arus Mutu Pendidikan: Menjawab Problematika Kontemporer Manajemen Mutu Pesantren,(Semarang: RaSAIL Media Group, 2011), 131.

17 Umiarso \& Nur Zazin, Pesantren di Tengah Arus Mutu Pendidikan, 142.

18 Abdul Rahman Assegaf, dkk, Pendidikan Islam di Indonesia, (Yogyakarta: Suka Press, 2007), 90 
(kebiasaan) uruf- a'raf; taqlid-taqaliid; turats ${ }^{19}$ Tradisi : adad kebiasaan turun menurun yang masih dijalankan dimasyarakat, penillaian atau anggapan bahwa cara-cara yang telah ada merupakan cara yang paling baik dan benar. ${ }^{20}$ Akademik; jami'i, madrasy;akadimy,nadhary; tajridy; ilmi ${ }^{21} \mathrm{Akademis}$ adalah bersifat ilmu pengetahuan. ${ }^{22}$

Dari penjelasan di atas bahwa tradisi akademik pesantren yang di maksudkan disini adalah kebiasaan-kebiasaan yang di budayakan yang bersifat pendidikan.

Tradisi Pengajaran Agama Islam, Salah satu tradisi agung("great tradition") di Indonesia adalah tradisi pengajaran agama Islam seperti yang muncul di pesantren jawa dan lembagalembaga serupa di luar jawa serta semenanjung Malaya. Alasan pokok munculnya pesantren ini adalah untuk mentranmisikan Islam tradisional sebaimana yang terdapat dalam kitab-kitab klasik yang ditulis berabadabad yang lalu. Kitab-kitab ini dikenal di Indonesia sebagai kitab kuning. Jumlah teks klasik yang diterima di pesantren sebagai ortodoks (al-kutub al-mu'tabarah) pada prinsipnya terbatas. Ilmu yang bersangkutan dianggap sesuatu yang sudah bulat dan tidak dapat ditambah; hanya bisa diperjelas dan dirumuskan kembali. Miskipun terdapat karya-karya baru, namun kandungannya tidak berubah. ${ }^{23}$

Tradisi Pembelajaran (sorogan,bandongan/wetonan), Dalam pelaksanaan pembelajaran dipesantren ada beberapa metode yang digunakan. Pertama, pengajaran diberikan secara individual. Seorang murid mendatangi seorang guru yang akan membacakam beberapa baris Qur'an atau kitab-kitab bagasa arab dan menerjemahkannya ke dalam bagasa jawa. Pada gilirannya, murid mengulangi dan menerkrmagkannya kata demi kata sepersis mungkin seperti yang dilakukan oleh gurunya. System penerjemahan dibuat sedemikian rupa sehingga para murid diharapkan mengetahui baik arti maupun fungsi kata dalam suatu kalimat bahasa Arab. Dengan demikian para murid dapat belajar

19 Nur Mufid, Kamus Modern Indonesia- arab al- Mufied(Surabaya: Pustaka Progresif, 2010), 716.

20 Kamus Besar Bahasa Indonesia, Departemen pendidikan dan kebudayaan( jakarta: Balai Pustaka, 1989), 959.

${ }^{21}$ Nur Mufid, Kamus Modern Indonesia- arab al- Mufied, 15.

22 Kamus Besar Bahasa Indonesia, Departemen pendidikan dan kebudayaan (Jakarta: Balai Pustaka, 1989),13.

23 Martin van Bruinessen, Kitab Kuning, Pesantren, Dan Tarekat: Tradisi-tradisi Islam Indonesia,(Bandung: Mizan, 1999) 
tatabagasa Arab langsung dari kitab-kitab tersebut. System individual ini dalam system pendidikan Islam tradisional disebut system sorogan yang diberikan dalam pengajian kepada muridmurid yang telah menguasai pembacaan Al-Qur'an.

Metode utama system pengajaran di lingkungan pesantren ialag system bandongan atau sering kali disebut system weton. Dalam system ini sekelompok murid (antara 5 sampai 500) mendengarkan seorang guru yang membaca, menerjemahkan, menerangakan dan seringkali mengulas buku-buku Islam dalam bahasa Arab. Setiap murid memperhatikan bukunya sendiri dam membuat catatan-catatan (baik arti maupun keteranganketerangan) tentanga kata-kata atau bauah pikiran yang sulit. Kelompok kelas dari system bandongan ini disebut halaqah yang arti bahasanya lingkaran murid, atau sekelompok siswa yang belajar dibawah bimbingan seorang guru. Dalam pesantren kadang-kadang diberikan juga system sorogan tetapi hanya diberikan kepada santri-santri baru yang masih memerlukan bimbingan individual.

System sorogan dalam pembelajaran pesantren ini merupakan bagian yang paling sulit dari keselulruhan system pendidikan tradisional, sebab system ini menuntut kesabaran, kerajinan, ketaatan dan disiplin pribadi dari murid. Kebanyakan murid-murid pengajian di pedesaan gagal dalam pendidikan dasar ini. Di samping itu banyak di antara mereka yang tidak menyadari bahwa mereka seharusnya mematangkan diri pada tingkat sorogan ini sebelum dapat mengikuti pendidikan selanjutnya di pesantren, sebab pada dasarnya hanya murid-murid yang menguasai system sorogan sajalah yang dapat memetik keuntungan dari system bandongan di pesantren.

System sorogan terbukti sangat efektif sebagai taraf pertama bagi seorang murid yang bercita-cita menjadi seorang alim. System ini memungkinkan seorang guru mengawasi, menilai dan membimbing secara maksimal kemampuan seorang murid dalam menguasai bahasa Arab. Dalam system bandongan, seorang murid tidak harus menunjukkan bahya ia mengerti pelajran yang sedang dihadapi. Para kyai biasanya membaca dan menerjemahkan kalimat-kalimat secara cepat dan tidak menerjemahkan kata-kata yang mudah. Dengan cara ini, kyai dapat menyelesaikan kitab-kitab pendek dalam beberapa minggu saja. ${ }^{24}$ System bandongan, karena dimaksudkan untuk murid-murid tingkat menengah dan tingkat

${ }^{24}$ Zamahsari Dhofier, Tradisi, 30. 
tinggi, hanya efektif bagi murid-murid yang telah mengikuti system sorogan secara intensif.

Muhawarah/ Muhadathah dan Muhadarah khitabah Muhawarah adalah suatu kegiatan berlatih bercakap-cakap dengan bahasa Arab yang diwajibkan oleh pesantren kepada para santri selama mereka tinggal di pondok. Di beberapa pesantren, latihan muhawarah atau muhadathah tidak diwajibkan setiap hari, akan tetapi hanya satu kali atau dua kali dalam seminggu, yang digabungkan dengan latihan muhadarah Khitobah, yang tujuannya adalah melatih para santri untuk belajar berpidato. ${ }^{25}$

Majlis Ta'lim, adalah suatu media penyampaian ajaran Islam yang bersifat umum dan terbuka. Para jama'ah terdiri dari berbagai lapisan yang memiliki latar belakang pengetahuan yang bermacamacam, dan tidak dibatasi oleh tingkatan usia maupun perbedaan kelamin. Pengajian seperti ini hanya diadakan dalam waktu-waktu tertentu saja. Ada yang seminggu sekali, dua minggu sekali atau satu bulansekali. Materi yang diberikan adalah nasehat-nasehat keagamaan yang bersifat al-amru bi al-ma'ruf wa al-nahyu'an almunkar. Ada kalanya materi di ambil dari kitab-kitab tertentu, seperti misalnya tafsir al-Qur'an dan al-Hadist. ${ }^{26}$

Tradisi akademik pesantren yang lainnya adalah, Tempat pengkaderan ulama, Wahana yang melahirkan sumber daya manusia yang handal dengan sejumlah predikat mulia yang menyertainya seperti: ikhlas, mandiri, penuh dengan perjuangan dan tabah serta mendahulukan kepentingan orang banyak daripada kepentingan dirinya. Semua predikat baik itu, juga diuji oleh kedahsyatan zaman dan tantangannya. Pemeliharaan Tradisi Islam Diantara pemeliharaan yang sangat sulit dalam pendidikan Islam adalah pemeliharaan terhadap tradisi Islam. Arus globalisasi yang terjadi saat ini seakan meruntuhkan pendidikan Islam. Ciri khas pendidikan Islam hilang dirampas oleh hingar-bingar perkembangan zaman yang sulit dikontrol. ${ }^{27}$

\section{Pembentukan Karakter Santri}

25 Anin Nurhayati, Kurikulum Inovasi: Telaah Terhadap Pengembangan Kurikulum Pendidikan Pesantren, (Yogyakarta: Teras, 2010), 56.

26 Anin Nurhayati, Kurikulum Inovasi, 57.

27 Moh. Wardi, Pengembangan Entrepreneurship Berbasis Experiential Learning di Pesantren Al-Amien Prenduan Sumenep dan Darul Ulum Banyuanyar Pamekasan. PhD thesis, UIN Sunan Ampel Surabaya, 2017, 86. 
Istilah "karakter" dipakai secara khusus dalam konteks pendidikan baru muncul pada akhir abad-18. ${ }^{28}$ Terminologi ini biasanya mengacu pada sebuah pendekatan idealis-spiritualis dalam pendidikan yang juga dikenal dengan teori pendidikan normatif. Yang menjadi prioritas adalah nilai-nilai tresenden yang dipercaya sebagai motor penggerak sejarah, baik bagi individu maupun bagi sebuah perubahan sosial. Kata Karakter dapat dipahami sebagai kpribaidian atau ahlak. Kata "akhlak" berasal kata bahasa Arab yang merupakan kata jama' dari kata "khuluq" yang berarti tabiat, budi pekerti, kebiasaan. Kata "khuluq" mengandung segi-segi kesesuaian dengan kata "khalqun" yang berarti kejadian, serta erat hubungannya dengan "khaliq" (pencipta), dan "makhluk" (yang diciptakan). Hal tersebut di atas mengandung makna bahwa rumusan pengertian "akhlak" timbul sebagai media yang memungkinkan adanya hubungan baik antara Khalik dengan Makhluknya dan antara Makhluk dengan Makhluk. Di samping itu, sumber akhlak adalah dari Khaliq (Allah SWT), dan juga dari Makhluq-Nya (Nabi/Rasulullah saw, dan atau manusia). ${ }^{29}$

Istilah akhlak juga mengandung etika dan moral. Etika adalah ilmu yang menyelidiki mana yang baik dan mana yagn buruk dengan memperhatikan amal perbuatan manusia sejauh yang dapat diketahui oleh akal pikiran. Sedangkan moral ialah sesuai dengan ide-ide yang umum diterima tentang tindakan manusia, mana yang baik dan wajar. Dalam kajian filsafat, istilah etika dibedakan denagn moral, yakni etika lebih bersifat teori, sedangkan moral lebih banyak bersifat praktis; etika memandang laku perbuatan manusia secar universal (umum), sedangkan moral secara local; dan moral menyatakan ukuran, sedangkan etika menjelaskan ukuran itu. ${ }^{30}$

Dalam jurnal internasional, The Journal of Moral Education, nilai-nilai dalam ajaran Islam pernah diangkat sebagai isu hangat yang dikupas secara khusus dalam volum 36 tahun 2007. Dalam diskusi pendidikan karakter ini memberikan pesan bahwa spritualitas dan nilai-nilai agama tidak bisa dilepaskan dari pendidikan karakter. Mural dan nilai-nilai spiritual sangat fundamental dalam membangun kesejahteraan dalam organisasi

28 Doni Koesoema A, Pendidikan Karakter: Strategi Mendidik Anak di Zaman Global, (Jakarta: PT. Grasindo, 2007), 9.

29 Muhaimin, Wacana Pengembangan Pendidikan Islam, (Yogyakarta, Pustaka Pelajar, 2003), 306.

30 Muhaimin, Wacana, 307 
social manapun. Tanpa keduanya, maka elemen vital yang mengikat kehidupan masyarakat dapat dipastikan lenyap. ${ }^{31}$

Dalam Islam, tidak ada disiplin ilmu yang terpisah dari etikaetika Islam. Dan pentingnya komperasi akal dengan wahyu dalam menentukan nilai-nilai moral terbuka untuk diperdebatkan. Bagi kebanyakan muslim segala yang dianggap halal dan haram dalam Islam, dipahami sebagai keputusan Allah tentang benar dan tidak. Dalam Islam terdapat tiga nilai utama, yaitu akhlak, adab, dan keteladanan.

\section{Penutup}

Kesimpulan dari tesis ini sebagai akhir dari penulisan berdasarkan hasil pemaparan data dan temuan penelitian serta pembahasahan temuan penelitian tersebut di atas, maka dapat disimpulkan hal-hal sebagai berikut:

Tradisi akademik pendidikan pesantren( $\left.\mathrm{ma}^{\prime} \mathrm{had}\right)$ al-Qalam MAN 3 Malang dan pesatren ( $\mathrm{ma}^{\prime} \mathrm{had}$ ) al-Ulya MAN Malang II Kota Batu memiliki nilai positif terhadap pembentukan katarakter santri, baik tradisi yang berkenaan dengan sistem pembelajaran maupun budaya belajar dalam kehidupan sehari-hari. Membangun tradisi akademik pesantren ( $M a^{\prime} h a d$ ) artinya adalah mendirikan tradisi yang bersifat akademik baik berkaitan sistem pembelajaran seperti lazimnya pada pesantren-pesantren lain, sistem tutorial dan pembinaan yang di wujudkan dalam bentuk kegiatan dan program program yang ada di ma'had. Tradisi akademik yang ada di pesantren( $\left.\mathrm{ma}^{\prime} \mathrm{had}\right)$ al-Qalam MAN 3 Malang dan pesantren ( $m a^{\prime} h a d$ ) al-Ulya MAN Malang II Kota Batu pada dasarnya tidak jauh beda dengan pesantren-pesatren pada lazimnya, baik dari segi materi keagamaan yang diberikan maupun metode pembelajaran yang digunakan seperti istilah yang sudah populer di kalangan pesantren yaitu metode sorogan, wetonan, bandongan, majlis ta'lim, Khitabah, dan muhawarah atau muhadathah, akan tetapi yang sedikit berbeda dengan pesantren pada umumnya utamanya pesantren salaf ialah tutorial untum materi-materi umum yang dipelajari disekolah agar santri bisa mepersiapkan diri untuk mengikuti kegiatan belajar di sekolah. selain itu ada bimbingan kebahasan utamanya bahasa arab dan bahasa inggris. Kemudian dari segi fasilitas hot spot dan loundry yang dipesantren lain jarang ada. Selain itu tradisi yang sangat diperhatikan dan sebagai ciri

31 Abdul Majid \& Dian Andayani, Pendidikan Karakter Perspektif Islam,(Bandung: PT Remaja Posdakarya, 2011), 58. 
khas dalam kalangn pesantren ialah tradsi kajian kitab kuning(KK). Di di pesantren ( $\mathrm{ma}^{\prime} \mathrm{had}$ ) al-Qalam dan pesantren ( $\mathrm{ma}^{\prime} \mathrm{had}$ ) al-Ulya juga diadakan kajian kitab kuning dan meterinya di sesuaikan dengan tingkatan atau kelas santri di sekolah.

Penanaman nilai-nilai luhur yang menjadi tradisi pesantren dalam pembentukan karakter santri di pesantren( $\mathrm{ma}^{\prime} \mathrm{had}$ ) alQalam MAN 3 Malang dan pesatren( $\mathrm{ma}^{\prime} \mathrm{had}$ ) al-Ulya MAN Malang II Kota Batu ialah melalui pembimbingan dan pembinaan seperti ubudiyah kemudian pembiasaan terhadap tradisi pesantren(budaya ma'hadi) dengan pembiasaan pola hidup seharihari dengan kesederhanaan, keihklasan, kemandirian dan menjalin ukhuwah Islamiyah dengan guru dan sesama santri. Dalam hal ini peran penagasuh ma'had dan para asatidz/asatidzah sangat penting dalam memberikan pembinaan dan pengembangan diri santri ke arah integritas kepribadian Islam, perluasan wawasan ilmu tentatang keislaman dalam upaya pembentukan karakter santri.Dengan pembiasaan mengikuti aturan yang ada di pesantren dalam upaya mendidik sikap dan mintal para santri agar memiliki kepribadian yang baik, maka pesantren(ma'had) al-Qalam dan pesantren ( $m a^{\prime} h a d$ ) al-Ulya selalu memberikan bimbingan dan pengarahan dan dirumuskan dalam betuk program dan kegiatan, sehingga dengan pembiasaan dengan budaya pesantren dalam pola kehidupan sehari-hari dengan dengan kesederhanaan, keihklasan, kemandirian dan menjalin ukhuwah Islamiyah sesama santri, maka akan tampak perubahan sikap dan tingkah pada diri para santri. 


\section{DAFTAR PUSTAKA}

Assegaf, Abdur Rahman. Pendidikan Islam di Indonesia, (Yogyakarta: SUKA Press, 2007)

Azra, Azyumardi. Pendidikan Islam :Tradisi dan Modernisasi Menuju Milenium Baru, (Jakarta: Logos Wacana Ilmu, 1999)

Bruinessen, Martin Van. Kitab Kuning, Pesantren, Dan Tarekat:

Tradisi-tradisi Islam Indonesia, (Bandung: Mizan, 1999)

Dhofir, Zamahsari. Tradisi Pesantren:Studi tentang Pandangan Hidup Kiyai. (Jakarta: LP3ES, 2011)

Departemen pendidikan dan kebudayaan. Kamus Besar Bahasa Indonesia. (Jakarta: Balai Pustaka, 1989)

Koesoema A, Doni. Pendidikan Karakter: Strategi Mendidik Anak di Zaman Global. (Jakarta: PT. Grasindo, 2007)

Muhaimin. Wacana Pengembangan Pendidikan Islam, (Yogyakarta: Pustaka Pelajar, 2003)

Maunah, Binti. Tradisi Intelektua Santri: Dalam Tantangan Dan Hambatan Pendidikan Pesantren di Masa Depan, (Yogyakarta: TERAS, 2009)

Mutaha, Ali. Kamus Mushahir; Kamus Arab Indonesia, (Jakarta: PT Mizan Publika, 2005)

Majid, Abdul \& Dian Andayani. Pendidikan Karakter Perspektif Islam, (Bandung: PT Remaja Posdakarya, 2011)

Mufid, Nur. Kamus Modern Indonesia- arab al- Mufied, (Surabaya: Pustaka Progresif, 2010)

Nasir, M. Ridlwan. Mencari Tipologi Format Pendidikan Ideal: Pondok Pesantren di Tengah Arus Perubahan, (Jakarta: Pustaka Pelajar, 2005)

Nurhayati, Anin. Kurikulum Inovasi: Telaah Terhadap Pengembangan Kurikulum Pendidikan Pesantren, (Yogyakarta: Teras, 2010)

Putra Daulay, Haidar. Sejarah Pertumbuhan dan Pembaruan Pendidikan Islam di Indonesia, (Jakarta: Kencana, 2007)

Qomar, Mujamil. Pesantren: Dari Transformasi Metodologi Menuju Demokratisasi Institisi, (Jakarta: PT. Gelora Aksara Pratama)

S. Karni, Asrori. Etos Studi Kaum Santri, Wajah Baru Pendidikan Islam, (Bandung: PT Mizan Pustaka, 2009)

Suharto, Babun. Dari Pesantren Untuk Umat: Reinventing Eksistensi Pesantren di Era Globalisasi. (Surabaya: Imtiyaz, 2011) 
Umiarso \& Nur Zazin. Pesantren di Tengah Arus Mutu Pendidikan: Menjawab Problematika Kontemporer Manajemen Mutu Pesantren, (Semarang: RaSAIL Media Group, 2011)

Wardi, Moh. Pengembangan Entrepreneurship Berbasis Experiential Learning di Pesantren Al-Amien Prenduan Sumenep dan Darul Ulum Banyuanyar Pamekasan. PhD thesis, UIN Sunan Ampel Surabaya, 2017 